\title{
滇池新运粮河水质季节变化及河岸带生态修复的影响”
}

\author{
王华光 ${ }^{1,2}$, 刘碧波 ${ }^{3}$, 李小平 ${ }^{1}$, 刘剑䑣 ${ }^{1 * *}$, 敖鸿毅 ${ }^{1}$, 李清曼 ${ }^{1}$ \\ (1: 中国科学院水生生物研究所,武汉 430072) \\ (2: 中国科学院研究生院, 北京 100049) \\ (3:河南工程学院,郑州 451191)
}

\begin{abstract}
摘 要: 新运粮河作为一条重要的滇池人湖河流,其水质直接影响滇池的生态健康与环境安全. 运用单因子水质标识指 数法探讨新运粮河下游水质季节变化规律及影响因子,并分析河岸带修复方式(护岸改造)对河流水质的影响. 结果表 明: 铵氮, 总氮, 总磷, 化学需氧量随时间变化明显. 在 5-10月的雨季,各指标浓度呈下降趋势, 11 月至次年 4 月的旱季, 降水量少, 各指标浓度呈上升趋势, 且显著高于雨季时浓度, 监测河段全年水质为劣 $\mathrm{V}$ 类. 木桩护岸河段营养盐去除率明 显高于直立混凝土堤岸河段的去除率, 同一护岸类型河段夏季去除率显著高于冬季.
\end{abstract}

关键词 : 滇池; 新运粮河;水质;季节变化;河岸带;生态修复

\section{Seasonal variation of water quality of Xinyunliang River, Dianchi Basin and the impact of the riparian ecological restoration}

\author{
WANG Huaguang ${ }^{1,2}$, LIU Bibo ${ }^{3}$, LI Xiaoping ${ }^{1}$, LIU Jiantong ${ }^{1}$, AO Hongyi ${ }^{1} \&$ LI Qingman ${ }^{1}$ \\ (1: Institute of hydrobiology, Chinese Academy of Sciences, Wuhan 430072, P. R. China) \\ (2: Graduate University of Chinese Academy of Sciences, Beijing 100049, P. R. China) \\ (3: Henan Institute of Engineering, Zhengzhou 451191, P. R. China)
}

\begin{abstract}
Xinyunliang River is one of the major rivers which flow into Lake Dianchi. Water quality of the river effects the ecological health and environmental safety of Lake Dianchi. We employed single factor pollution indexes to investigate the seasonal variation of the water quality and the main factors which affect the quality. We studied the impact of the riparian ecological restoration on the river water quality taking the lower reaches of Xinyunliang River as an example. The results showed that there were obvious temporal variations in the concentration of ammonia nitrogen, total nitrogen, total phosphorus and chemical oxygen demand. All of the indicates showed declined tendency from May to November which is coincided with the rainy season, and were increased and significantly higher than those from November to next year's April, the dry season. The quality of the water is much worse than Grade V. The removal efficiency of pollutant in timber pile banks was higher than that in vertical cement banks. The removal efficiency in summer is much higher than that in winter.
\end{abstract}

Keywords: Lake Dianchi; Xinyunliang River; water quality; seasonal variation; riparian; ecological restoration

随着现代经济的迅速发展,河流污染问题日益严重. 河流水质不仅受降水、大气沉降等自然因素的影 响,而且还受工业和城市废水以及农田地表径流等人文因素的影响 ${ }^{[1]}$. 人湖河流是湖泊的主要水量来源, 也 是污染物进人湖泊的主要通道, 大部分点源与面源污染物通过人湖河流进人湖泊 ${ }^{[2]}$. 控制人湖河流污染是 削减湖泊污染的重要途径 ${ }^{[3]}$. 自 $1970 \mathrm{~s}$ 以来, 滇池水体及入湖河道水质不断恶化, 富营养化程度不断加 剧. 近年来随着治理工作的加强, 点源污染得到一定控制, 但滇池水体及主要人湖河流水质仍处于 $\mathrm{V}$

* 国家水体污染控制与治理科技重大专项项目 (2009ZX07102-003-4)、淡水生态与生物技术国家重点实验室自主项 目 (2009FBZ09) 和国家重点基础研究发展计划“973”项目(2009CB118705)联合资助. $2011-07-05$ 收稿; 201110-25 收修改稿. 王华光,男,1986 年生,硕士研究生;E-mail:whggfff@ 126.com.

** 通信作者;E-mail:jtliu@ihb. ac. cn. 
类或劣 $\mathrm{V}$ 类 ${ }^{[4-6]}$. 本文通过对滇池一条重要人湖河流——新运粮河的下游及人湖口水质进行长期监测, 分析人滇池河道各月份水质变化, 尤其是雨季和旱季污染物浓度的差异, 为滇池流域河流入湖污染控 制提供依据.

于一雷等 ${ }^{[7]}$ 研究发现密云水库人库污染物主要来自汛期, 丰水期河流水体营养盐浓度高于枯水期, 这 一结果与一些学者对滇池流域 ${ }^{[5]}$ 、浑河流域 ${ }^{[8]}$ 、闽江流域 ${ }^{[9]}$ 以及新运粮河进行研究发现的变化规律相反. 其 中王自林等 ${ }^{[5]}$ 对滇池不同人湖河道污染物季节变化进行研究, 发现流经昆明主城区的河流旱季污染物浓度 明显高于雨季,与本文结果相同.

国内外关于河岸带生态修复的研究很多 ${ }^{[10-18]}$. 河岸带是河流生态系统的重要组成部分, 是河流水体与 近岸陆地之间物质和能量交换的纽带, 对河流生态平衡起到重要作用. 传统的河岸多采用浆砌石块或混凝 土方式切断了水体与近岸陆地的联系, 破坏水生生态系统结构与功能, 河流对外源污染负荷的抗冲击能力 减弱 ${ }^{[19]}$. 相对于传统的护岸方式, 各种河岸带生态修复措施能不同程度地恢复河流自净功能 ${ }^{[1,20]}$. 研究滇 池流域人湖河流污染物浓度的季节变化特征及河岸带修复在重污染河流中的应用效果, 能够为有效地治理 人滇池河流、保护滇池生态环境、改善城市生态环境提供依据.

\section{1 研究区域与方法}

\section{1 研究区域概况}

新运粮河是一条重要的滇池人湖河流,是昆明市主 城区西部最长的防洪、排涝河道, 主河道全长 $21 \mathrm{~km}$, 含 15 条主要支流, 全段无沿河截污管,各种人河排污口 323 个,河流流量小,流速较小,河段不同水期污染程度不同， 丰水期的水质好于枯水期. 由于河流两岸不断注人大量 污染物, 同时在河道整治过程中忽视了河道整体的生态 治理和修复,河段水质不断恶化 ${ }^{[21]}$,水体发黑、发臭, 基 本丧失了使用功能. 研究选取下游至人湖口的 $2 \mathrm{~km}$ 河段, 该河段属于缓流、滞流型水体,水位落差小,水流缓慢, 且 时常受滇池水顶托,长期处于黑臭状态, 水中基本没有水 生植物. 前后共设 6 个采样点 (图 1), 涵盖两种堤岸类型 及人湖口. 其中, $1^{\#}$ 点和 $2^{\#}$ 点之间的河段进行了河岸带生 态修复建设,在原有混凝土堤岸内侧, 使用木桩泥土护岸 方式, 填土后种植水生植物. $4^{\#}$ 点和 $5^{\#}$ 点之间的河段以直 立混凝土护岸为主,由于失去栖息地,无水生植物生长.

\section{2 采样与分析方法}

2009 年 10 月至 2011 年 4 月于上述采样点采集水 样, 现场用 YSI 550A 测定温度 ( T) 、溶解氧 ( DO), 用 YSI60 测定 $\mathrm{pH}$ ，用萨氏盘测定透明度 $(\mathrm{SD})$. 采集 $500 \mathrm{ml}$

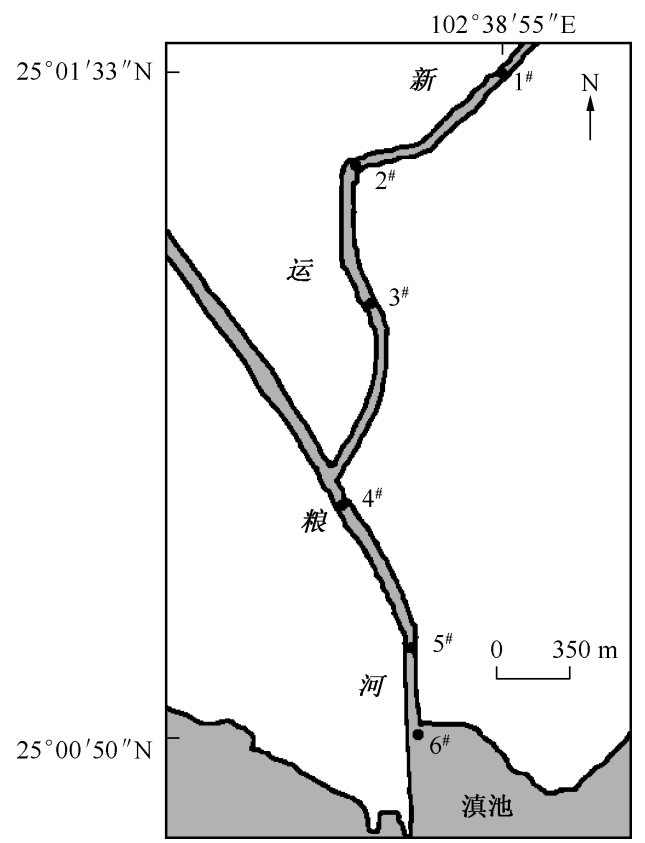

图 1 新运粮河下游河段采样点分布

Fig. 1 Distribution of sampling sites of the lower reaches of Xinyunliang River 水样装瓶, 回实验室 $12 \mathrm{~h}$ 内测定其他理化指标. 总磷 $(\mathrm{TP})$ 、铵氮 $\left(\mathrm{NH}_{4}^{+}-\mathrm{N}\right)$ 、化学需氧量 $\left(\mathrm{COD}_{\mathrm{Cr}}\right)$ 分别采用钼酸铵分光光度法、纳氏试剂法和重铬酸钾法测定 ${ }^{[22]}$.

由于水体污染严重, 总氮 ( TN) 含量很高,严格按照《水和废水监测分析方法》中的总氮测定方法无法 准确测定其浓度, 导致 2009 年 10 月、12 月和 2010 年 4 月的总氮测定结果偏小, 该部分数据做缺失处理. 2010 年 6 月开始采用修改后的总氮测定方法 ${ }^{[23]}$, 先取适量水样加人螺口消解管内, 加碱性过硫酸钾氧 化, 氧化后水样用酚二磺酸法测硝态氮含量, 最后换算成水样中总氮浓度. 该方法能更准确地测得水中总 氮的浓度.

数据分析采用单因子水质标识指数法 ${ }^{[24]}$ 来探讨主要污染物及其污染程度. 利用 Origin 8.0 软件进行 作图。 


\section{2 结果与讨论}

\section{1 河段营养盐浓度的季节变化}

各采样点 $\mathrm{NH}_{4}^{+}-\mathrm{N}, \mathrm{TN}, \mathrm{TP}, \mathrm{COD}_{\mathrm{Cr}}$ 含量均有明显季节变化, 且变化趋势相似(图 2). 2009 年 12 月到 2010 年 4 月各指标值增大, 在 4 月或 6 月出现最大值, 之后逐渐降低, 到 10 月出现最低值, 之后又升高. 第二个高 峰值显著低于第一个高峰值. 2011 年 3 月各指标值低于前后两次监测数据, 可能是采样前降雨、滇池蓄水后 水质较好的草海水回灌造成的.

$\mathrm{NH}_{4}^{+}-\mathrm{N}$ 由 2010 年 4 月最高值 $71.97 \mathrm{mg} / \mathrm{L}$ 迅速降至 6 月份的 $13.68 \mathrm{mg} / \mathrm{L}$, 之后继续降低, 10 月到达最 低值. $\mathrm{TN}$ 变化与 $\mathrm{NH}_{4}^{+}-\mathrm{N}$ 一致,从 6 月份的 $15.4 \mathrm{mg} / \mathrm{L}$ 持续下降至 10 月达到最低值 $8.11 \mathrm{mg} / \mathrm{L}$.

$\mathrm{TP}$ 由 4 月最高值 $7.36 \mathrm{mg} / \mathrm{L}$ 快速降至 6 月份最低值达到 $0.84 \mathrm{mg} / \mathrm{L}$, 然后在 $1.00 \mathrm{mg} / \mathrm{L}$ 左右小幅变化. $\mathrm{COD}_{\mathrm{Cr}}$ 值变化与 TP 变化趋势一致,由 4 月份的 $138.07 \mathrm{mg} / \mathrm{L}$ 降至 $35.73 \mathrm{mg} / \mathrm{L}$, 之后变化缓慢.
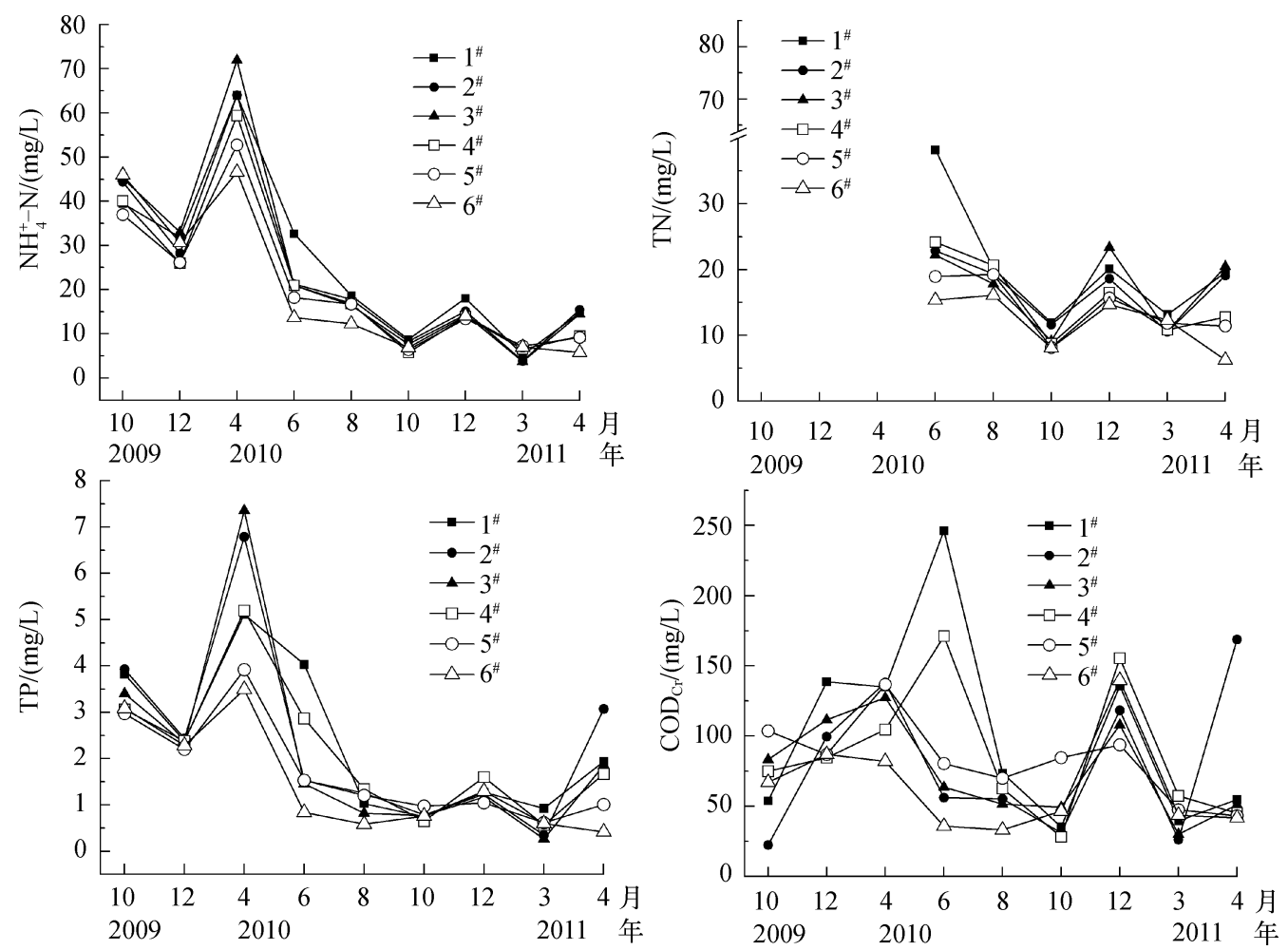

图 2 河段各采样点 $\mathrm{NH}_{4}^{+}-\mathrm{N} 、 \mathrm{TN} 、 \mathrm{TP} 、 \mathrm{COD}_{\mathrm{Cr}}$ 含量的季节变化

Fig. 2 Seasonal variations of the concentrations of $\mathrm{NH}_{4}^{+}-\mathrm{N}, \mathrm{TN}, \mathrm{TP}, \mathrm{COD}_{\mathrm{Cr}}$ for each sampling site

本文对新运粮河的水质季节变化的研究结果与王自林等 ${ }^{[5]}$ 对滇池主要人湖河道水体氮磷污染物浓度 变化的研究结果一致:流经城区的河流水质较差, 且雨季污染物浓度低于旱季. 说明面源污染对流经城区的 河流水质影响较小, 在降水量较大的雨季, 河道补水会显著降低河流污染物浓度.

上游大量生活污水及工业污水是河水中营养盐的主要来源. 监测河段较短, 除 $4^{\#}$ 点前段有条支流带来 大量污染物, 无其他明显的污染源. 各指标浓度变化主要受降雨的影响, 滇池流域雨季主要受季风缓流控 制, 具有明显的季节性, 多年平均降雨量为 $1035.3 \mathrm{~mm}$, 雨季 $(5-10$ 月) 降雨量占 $83 \% .11$ 月至次年 4 月是 滇池周边地区的旱季, 降水量少, 新运粮河雨水补给少, 污染物不能得到稀释, 各指标浓度较高. 2010 年 4 月 因西南大干旱而导致各指标浓度偏高, 出现高峰值, 之后雨季到来, 大量雨水进人河流, 各指标浓度快速 降低. 
河流水质变化不仅受降水量影响,不同时期温度差异也是影响水质的重要因素. 微生物的净化功能是 河段水体自净的重要组成部分. 温度对硝化反应有重要影响, 当温度低于 $15^{\circ} \mathrm{C}$ 时, 硝化反应明显受到抑 制 ${ }^{[25]}$. 冬季气温低 $\left(12\right.$ 月水温约为 $14^{\circ} \mathrm{C}$ ), 水体中微生物活性降低, 代谢活动减弱, 铵态氮等化合物转化效 率降低, 有机化合物消耗量降低, 致使水体中各污染物浓度较高. 夏季气温升高 $\left(8\right.$ 月水温约为 $\left.24^{\circ} \mathrm{C}\right)$, 微生 物活性升高, 有利于水体中的铵态氮转化为硝态氮和亚硝态氮 ${ }^{[26]}$, 进一步以氮气的形式离开水体, 同时有机 污染物去除量也升高. 因此温度差异是造成冬季河段各污染物浓度高于夏季的一个重要因素.

河水溶解氧也是影响水质的重要因素. 监测河段由于河水污染严重, 透明度低 $(\mathrm{SD} \leqslant 40 \mathrm{~cm})$, 溶解氧低 $(\mathrm{DO}<1.0 \mathrm{mg} / \mathrm{L})$, 水生生态系统结构与功能受到严重破坏. 有机物污染严重的河流, 水中硝化细菌等好氧 微生物进行代谢反应消耗水中氧气, 其耗氧速率大于水体复氧速率, 导致水中的溶解氧含量下降, 甚至消耗 殆尽而出现无氧状态, 有机物也主要以厌氧降解和缺氧降解的方式进行 ${ }^{[27]}$. 细菌厌氧分解产生氨、硫化氢、 挥发性有机酸等恶臭物质, 以及铁、锰的硫化物等黑色物质, 是河水发黑、发臭的原因之一. 雨季期间流人河 流的雨水含丰富的氧气,使好氧微生物代谢加强, 有利于水质改善.

近年来随着滇池流域治理投资的增加, 上游污染源截污工作的加强, 污染严重的工业全部迁出该流域, 生活污水直接向河道排放的量也减少, 上游污染负荷降低, 导致后期各指标与过去同期相比有所改善.

\section{2 单因子水质标识指数法评价水质}

单因子水质标识指数法既能对水质类别进行评价, 又能在同一类水的水质指标中进行定量比较 ${ }^{[24]}$. 可 以完整刻画评价指标的水质类别、水质数据与水环境功能区类别的比较情况.

单因子水质指数 $P$ 由整数及小数点后二位或三位有效数字组成, 表示为: $P_{i}=X_{1} . X_{2} X_{3}$, 式中, $X_{1}$ 代表第 $i$ 项水质指标的水质类别, $X_{2}$ 代表监测数据在 $X_{1}$ 类水质变化区间中所处的位置, $X_{3}$ 代表水质类别与功能区划 设定类别的比较结果.

当水质劣于或等于 $\mathrm{V}$ 类水时, 对于 $\mathrm{TN}$ 、 $\mathrm{TP}$ 、 $\mathrm{NH}_{4}^{+}-\mathrm{N} 、 \mathrm{COD}_{\mathrm{Cr}}$ 的计算, $X_{1} . X_{2}=6+\left(C_{i}-\right.$ $\left.C_{\mathrm{V} \text { 类标上 }}\right) / C_{\mathrm{V} \text { 类标上, }} X_{3}=X_{1}-f_{1}$, 式中, $C_{\mathrm{V} \text { 类标上 }}$ 为第 $i$ 项指标 $\mathrm{V}$ 类水标准上限, $f_{1}$ 为水环境功能类别.

对监测数据按照单因子水质标识指数法进 行计算, 然后取 6 个点计算结果的平均值 ${ }^{[28]}$, 结 果表明 (图 3 ), 所有 $X_{1} . X_{2}$ 值均大于 6 , 即所有指 标均为劣 $\mathrm{V}$ 类水, 但各指标污染程度不同. $\mathrm{TN}$ 标 识指数最小值为 9.8 , 最大值为 16.8 , 表明 $\mathrm{TN}$ 浓 度最低时为 $\mathrm{V}$ 类水质上限的 4.8 倍, 而最高为 11.8 倍. $\mathrm{TP}$ 标识指数最小值为 6.3 , 最大值为 16.3 , 表明 $\mathrm{TP}$ 最小监测值为 $\mathrm{V}$ 类水质上限的 1.3 倍, 而最大值为 11.3 倍. $\mathrm{NH}_{4}^{+}-\mathrm{N}$ 标识指数最 小值为 7.8 , 最大值为 34.9 , 分别是 $\mathrm{V}$ 类水质上 限的 2.8 倍和 29.9 倍. $\mathrm{COD}_{\mathrm{Cr}}$ 标识指数变化较 小, 在 $6.0 \sim 8.0$ 之间, 分别为 $\mathrm{V}$ 类水质上限的 1.0 倍和 3.0 倍. 总体而言, $\mathrm{TN} 、 \mathrm{NH}_{4}^{+}-\mathrm{N}$ 的污染

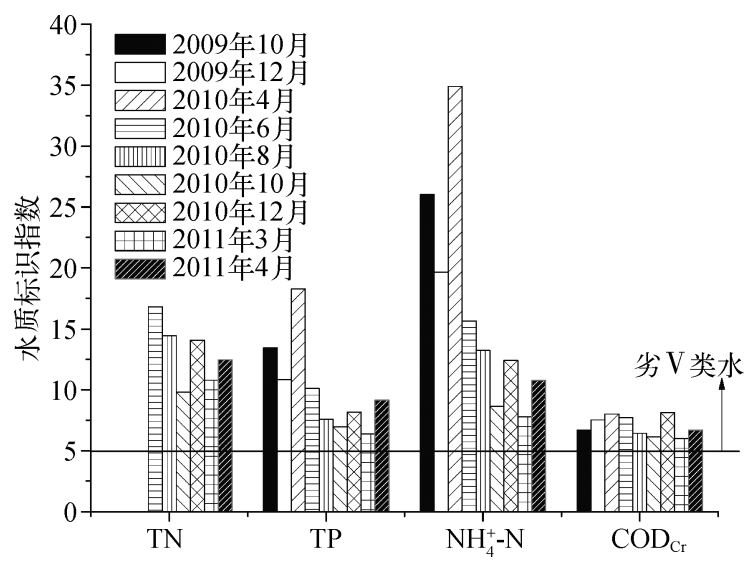

图 34 项指标的单因子水质标识指数的比较

Fig. 3 Comparison of four water quality items based on the single factor water quality identification indexes 最为严重, $\mathrm{TP}$ 次之, $\mathrm{COD}_{\mathrm{Cr}}$ 污染最轻.

\section{3 河段营养盐浓度与河岸带结构的关系}

$1^{\#}$ 点至 $2^{\#}$ 点之间河段已完成河岸带生态修复工程. 在原有混凝土堤岸内侧, 设置一排木桩, 上面固定合 适孔径的防腐铁丝网, 混凝土墙与木桩之间填充泥土, 泥土上端及满足透明度要求的侧面长满水花生等水 生植物 (图 4); $4^{\#}$ 点至 $5^{\#}$ 点之间河段为未修复河段, 两岸为光面直立混凝土护岸, 无水生植物生长. 两河段长 度相似,约为 $280 \mathrm{~m}$.

2010 年 6 月份监测数据代表雨季,2010 年 12 月数据代表旱季. 选取的两个河段, 没有明显的点源污染, 


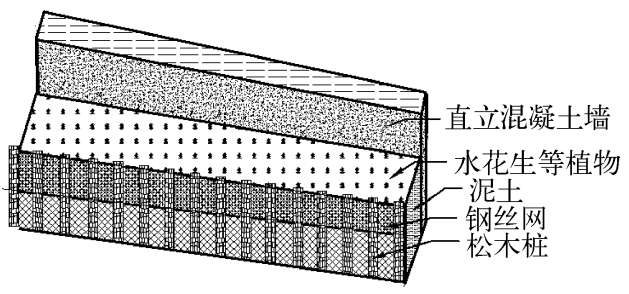

图 4 河岸带生态修复示意图

Fig. 4 Schematic diagram of the riparian ecological restoration

假设没有任何外源污染物, 粗略计算各营养盐的去除率. 结果表明, 6 月份直立混凝土护岸河段 $\mathrm{TN} 、 \mathrm{TP} 、 \mathrm{NH}_{4}^{+}-\mathrm{N}$ 、 $\mathrm{COD}_{\mathrm{Cr}}$ 的去除率分别为 $21.62 \% 、 46.63 \% 、 13.22 \%$ 、 $53.05 \%$,生态护岸河段 $\mathrm{TN} 、 \mathrm{TP} 、 \mathrm{NH}_{4}^{+}-\mathrm{N} 、 \mathrm{COD}_{\mathrm{Cr}}$ 的去除率 分别为 $40.17 \% 、 62.10 \% 、 34.88 \% 、 77.25 \% .12$ 月份直 立混凝土护岸河段 $\mathrm{TN} 、 \mathrm{TP} 、 \mathrm{NH}_{4}^{+}-\mathrm{N} 、 \mathrm{COD}_{\mathrm{Cr}}$ 的去除率分别 为 $4.77 \% 、 2.93 \% 、 3.49 \% 、 11.28 \%$,生态护岸河段 $\mathrm{TN}$ 、 $\mathrm{TP} 、 \mathrm{NH}_{4}^{+}-\mathrm{N} 、 \mathrm{COD}_{\mathrm{Cr}}$ 的去除率分别为 $7.53 \% 、 3.67 \%$ 、 $16.37 \% 、 12.87 \%$ (图 5).

由此可以看出,相对于传统的混凝土护岸方式,采用 木桩泥土护岸方式可以更高效地去除水体中的营养盐. 雨季期间的 6 月份净化效果更加显著. 12 月份两种护岸方式的营养盐去除率都比较低,但生态护岸河段比 直立混凝土护岸的去除效率略高.

木桩护岸具有良好的透水透气性能, 保证河流生态系统和陆地生态系统之间的物质交换和能量流动, 为河岸带动植物、微生物的栖息繁衍提供栖息地. 相对于混凝土护岸, 木桩生态护岸具有更大的比表面积、 更强的吸附性能, 为微生物的富集提供良好的条件 ${ }^{[19]}$. 增大水体中污染物与微生物的接触,使水质得到更好 的改善. 泥土上生长的植物自身可吸收、转化利用水体中的营养盐, 植物根系向水体释放氧气, 为微生物提 供营养物质,有利于微生物的生长, 增强微生物净化水体功能.
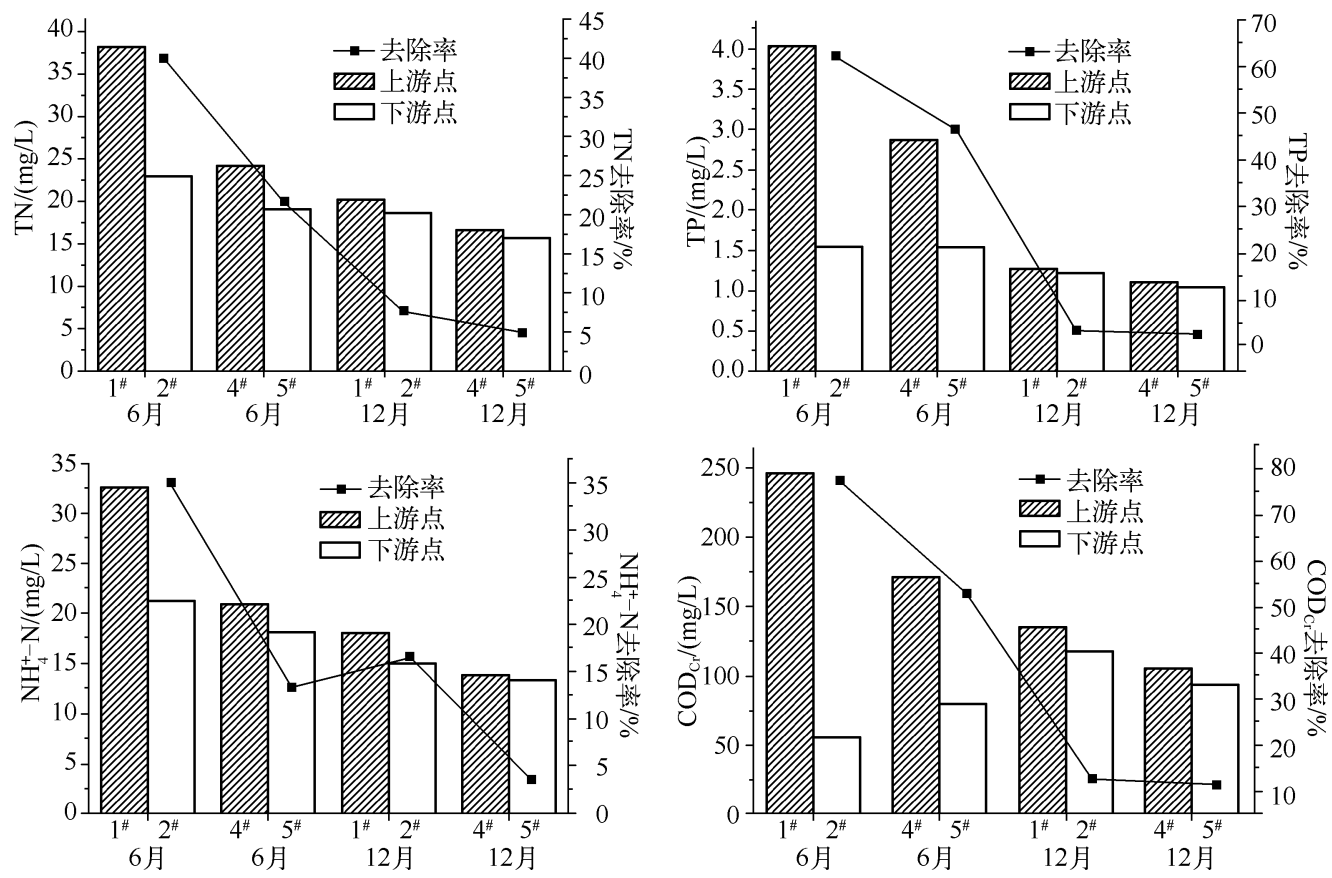

图 5 不同时间和河段的总氮、总磷、铵氮、COD $\mathrm{Cr}$ 浓度及去除率变化

Fig. 5 Variations of the concentrations and removal rates of TN, TP, $\mathrm{NH}_{4}^{+}-\mathrm{N}, \mathrm{COD}_{\mathrm{Cr}}$ in different time and reaches

监测河段以混凝土护岸和木桩护岸为主. 河流内部生态系统严重退化, 自净能力低. 直立混凝土护岸完 全隔绝河水与岸带的联系. 木桩护岸保证河水和岸带有一定的联系,但由于水质污染严重, 木桩护岸净化水 质功能受到限制. 河流水体依然黑臭, 水体溶解氧低, 透明度低, 没有有效地恢复河段的生物多样性,生态系 
统结构和功能没有得到有效改善. 河流失去生物对水质的净化作用,水体自净功能严重退化 ${ }^{[29]}$. 国内外研 究 ${ }^{[29-31]}$ 表明, 只有重建和修复河流生态系统,增加生物多样性,通过生物阻滞、降解、转化、去除污染,优化生 态系统结构与功能,增强河流自净能力,才能有效减少人湖河流对滇池湖泊的污染.

要充分利用部分人滇池河道自身空间净化水质,如在河道内布设人工水草、人工浮床、人工沉床等,加 强对氮磷污染物的去除. 多种河流治理技术已经在国内外得到实践,其中针对溶解氧低的情况,可以适当地 进行人工曝气,制造出浅滩和深潭交错 ${ }^{[30-32]}$ 的河道,有利于水体的大气复氧. 水体透明度低可以通过人工种 植水草, 提高微生物量, 增强微生物净化水质效果以及采用人工浮床 ${ }^{[33]}$ 和沉床 ${ }^{[34-36]}$ 等手段进行改善. 修筑缓 坡不仅可以增加水体与土壤之间物质能量交换, 而且在透明度及水深合适的区域,水生植物可以生长, 从而 增强水质净化,为其他生物提供栖息地,有利于生态系统的恢复.

\section{3 结论}

1）新运粮河下游水质 $\mathrm{TN} 、 \mathrm{TP} 、 \mathrm{NH}_{4}^{+}-\mathrm{N} 、 \mathrm{COD}_{\mathrm{Cr}}$ 呈现明显的季节变化. 旱季降雨量少,各指标较高,雨季降 雨量大,各指标较低. 各指标的高峰值大都出现在 2010 年 4 月,主要原因是西南地区大干旱,降水稀少, 排人 河道的工业、生活污水的营养盐得不到稀释. 最低值出现在 2010 年 10 月,主要原因是雨季的降水不断补给 河流,使外源污染得到稀释. 除受降雨量影响外,温度的季节差异等也是造成水质波动的原因. 总体来说,新 运粮河下游水体污染严重, 流人滇池的营养盐负荷较大,尤其是早季的 12 月到次年的 4 月,针对这期间的水 质防控尤为重要.

2 ) 河段全年水质均为劣 $\mathrm{V}$ 类, 是所有滇池人湖河流中污染较严重的河流,其各指标污染程度不同. TN、 $\mathrm{NH}_{4}^{+}-\mathrm{N}$ 的污染最为严重, $\mathrm{NH}_{4}^{+}-\mathrm{N}$ 最大值是 $\mathrm{V}$ 类水质上限的 29.9 倍, $\mathrm{TP}$ 次之, $\mathrm{COD}_{\mathrm{Cr}}$ 污染最轻, 为 $\mathrm{V}$ 类水质 上限的 $1 \sim 3$ 倍.

3 ) 河岸带生态修复与传统混凝土护岸河段的 $\mathrm{TN} 、 \mathrm{TP} 、 \mathrm{NH}_{4}^{+}-\mathrm{N} 、 \mathrm{COD}_{\mathrm{Cr}}$ 去除率明显不同. 生态护岸河段各 指标去除率显著高于直立混凝土护岸河段, 且夏季去除率明显高于冬季. 河岸带生态修复能有效增强水体 自净功能.

\section{4 参考文献}

[ 1 ] Song K, Lee SH, Mitsch WJ et al. Different responses of denitrification rates and denitrifying bacterial communities to hydrologic pulsing in created wetlands. Soil Biology and Biochemistry, 2010, 42(10) :1721-1727.

[2] 金相灿, 辛玮光, 卢少勇等. 人湖污染河流对受纳湖湾水质的影响. 环境科学研究, 2007, 20:52-56.

[3] 李海英, 冯慕华, 李 玲等. 微曝气生态浮床净化人湖河口污染河水原位模型实验. 湖泊科学, 2009, 21 : $782-788$.

[ 4 ] 徐晓梅, 张琨玲. 影响滇池人湖污染物总量变化的主要因素分析. 云南环境科学, 2004, 23: 42-44.

[5] 王自林, 李永梅, 张维理等. 滇池主要人湖河道口旱季/雨季水体氮磷污染物变化研究. 云南农业大学学报: 自 然科学版, 2009, $24: 729-733$.

[6] 陈建军. 滇池主要人湖河流水质分析. 云南农业大学学报, 2005, 20: 569-572.

[ 7 ] 于一雷, 王庆锁. 密云水库及其主要河流人库河段水质的季节变化. 中国农业气象, 2008, 29: 432-435.

[8] 张鸿龄. 浑河流域水体污染的季节性变化及来源. 生态学杂志, 2011, 30(1): 119-125.

[9] 陈涵贞，苏德森，吕 新等. 闽江流域地表水质季节性变化特征研究. 中国农学通报, 2010,26(5):267-271.

[10］郭会哲, 㚞 巍, 宋绪忠. 河岸带植被结构功能及修复技术研究进展. 河南林业科技, 2005, 25(4)：1-3.

［11］邓红兵，王青春，王庆礼等. 河岸植被缓冲带与河岸带管理. 应用生态学报, 2001,12: 951-954.

[12] 高晓琴. 南通市城市生态河道构建理论及其应用 [学位论文]. 南京: 南京林业大学, 2008.

[13] 刘义涛. 人库河道近自然生态修复实验研究 [学位论文]. 长春: 东北师范大学, 2009.

[14] 张宇博. 受损河岸生态系统生态恢复的效果研究 [ 学位论文]. 长春: 东北师范大学, 2008.

[15] Craig LS, Palmer MA, Richardson DC et al. Stream restoration strategies for reducing river nitrogen loads. Frontiers in Ecology and the Environment, 2008, 6: 529-538.

[16] Nilsson C, Brown RL, Jansson R et al. The role of hydrochory in structuring riparian and wetland vegetation. Biological Reviews, 2010, 85 : 837-858. 
[17] Baldigo BP, Ernst ASG, Keller W et al. Restoring geomorphic stability and biodiversity in streams of the Catskill Mountains, New York, USA. In: Nielsen J, Dodson JJ, Friedland K eds. American fisheries society symposium. Amer Fisheries Soc, 2008: 1777-1790.

[18] Clews E, Vaughan IP, Ormerod SJ. Evaluating the effects of riparian restoration on a temperate river-system using standardized habitat survey. Aquatic Conservation-Marine and Freshwater Ecosystems, 2010, 20: S96-S104.

[19] Olson DH, Anderson PD, Frissell CA et al. Biodiversity management approaches for stream-riparian areas: Perspectives for Pacific Northwest headwater forests, microclimates, and amphibians. Forest Ecology and Management, 2007,246 : $81-107$.

[20] Huang JC, Mitsch WJ, Zhang L. Ecological restoration design of a stream on a college campus in central Ohio. Ecological Engineering, 2009, 35: 329-340.

[21] 陈 灿, 王国祥, 朱增银等. 城市人工湖泊水生植被生态恢复技术. 湖泊科学, 2006, 18: 523-527.

[22] 魏复盛. 水和废水监测分析方法. 北京: 中国环境科学出版社, 2002 .

[23] 郭姿珠. 水体中总氮测定方法的研究 [学位论文]. 长沙: 中南大学, 2008 .

[24] 徐祖信. 我国河流单因子水质标识指数评价方法研究. 同济大学学报: 自然科学版, 2005, 33: $321-325$.

[25] Fleming-Singer MS, Horne AJ. Enhanced nitrate removal efficiency in wetland microcosms using an episediment layer for denitrification. Environmental Science \& Technology, 2002, 36 : 1231-1237.

[26] 李娟英, 赵庆祥. 低浓度铵氮硝化过程中影响因素的研究. 环境污染与防治, 2006, 28:11-13.

[27] 李晓东, 孙铁珩, 李海波等. 人工湿地除磷研究进展. 生态学报, 2007, 27(3) : 1226-1232.

[28] Evans-White MA, Dodds WK, Huggins DG et al. Thresholds in macroinvertebrate biodiversity and stoichiometry across water-quality gradients in Central Plains( USA) streams. Journal of the North American Benthological Society, 2009 , 28: $855-868$.

[29] Decamps H, Pinay G, Naiman RJ et al. Riparian zones: Where biogeochemistry meets biodiversity in management practice. Polish Journal of Ecology, 2004, 52: 3-18.

[30] 赵光影, 刘景双, 王 洋等. 三江平原主要河流氮, 磷营养元素时空变化规律研究. 干旱区资源与环境, 2009, 52(2) : 144-149.

[31］倪晋仁, 刘元元. 论河流生态修复. 水利学报, 2006, 37: 1029-1037.

[32] 赵庆良, 马建华. 基于信息熵的评价模型在惠济河水质评价中的应用. 河南大学学报: 自然科学版, 2002, 32: 76-80.

[33] 黄廷林, 宋李桐, 钟建红等. 人工浮床净化城市景观水体的实验研究. 西安建筑科技大学学报: 自然科学版, 2007,39 ( 1 ) : 30-33.

[34] 程南宁, 朱 伟, 张 俊. 重污染水体中沉水植物的繁殖及移栽技术探讨. 水资源保护, 2004, 20: 8-11.

[35] 戴全裕, 蒋兴昌. 太湖人湖河道污染物控制生态工程模拟研究. 应用生态学报, 1995, 6: 201-205.

[36] 杨逢乐, 金竹静. 滇池北岸河流水环境污染现状及防治对策研究. 环境科学导刊, 2008, 27: 43-46. 